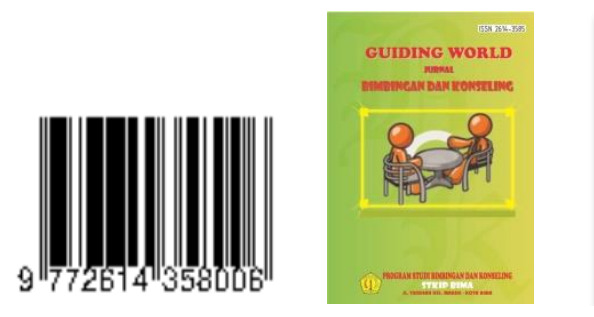

\title{
Relasi Kekerabatan Antarbahasa Sasak-Sumbawa-Bima Ditinjau Dari Letak Geografisnya
}

\author{
Irham \\ Prodi Bimbingan dan Konseling, Sekolah Tinggi Keguruan Dan Ilmu Pendidikan (STKIP Bima) \\ Email: Irham@gmail.com
}

\begin{abstract}
Abstrak
Ilmu bahasa yang menyelidiki dan mengkaji secara ilmiah disebut ilmu linguistik. Ilmu linguistik tidak hanya mengkaji sebuah bahasa saja, melainkan mengkaji seluk-beluk bahasa pada umumnya. Ilmu linguistik dapat mempelajari bahasa secara sinkronis dan diakronis. Studi sinkronis ini bersifat deskriptif, karena linguistik hanya mencoba memberikan gambaran keadaan bahasa menurut apa adanya pada kurun waktu yang terbatas. Secara diakronis, artinya mempelajari bahasa dengan pelbagai aspeknya dan perkembangannya dari waktu ke waktu sepanjang kehidupan bahasa itu. Studi bahasa secara diakronis ini disebut linguistik bistoris komparatif. Linguistik historis komparatif merupakan cabang linguistik yang mempersoalkan bahasa dalam bidang waktu serta perubahan-perubahan unsur bahasa yang terjadi pada kurun waktu tertentu serta menyelidiki perbandingan suatu bahasa dengan bahasa lain. Penelitian linguistik historis komparatif (LHK) terhadap bahasa-bahasa di wilayah geografis Nusa Tenggara, yang meliputi Bali, NTB, dan NTT telab dilakukan oleh para abli. Terbukti sejumlah karya tulis berupa disertasi yang menelaah sejarah bahasa-bahasa sekerabat di wilayah tersebut telah dilakukan oleh para abli. Penelitian bahasa-bahasa di wilayah geografis NTB yang telah ada pada umumnya masib bersifat sendiri-sendiri atau hanya meneliti pada satu bahasa saja atau bahasa-bahasa yang berkerabat saja, sedangkan penelitian ke arah perbandingan bahasa yang tidak. berkerabat namun masih dalam satu wilayah geografis masih belum dilakukan secara komprehensif. Berkaitan dengan masalah tersebut, artikel ini akan membahas tentang: "Relasi Kekerabatan Antarbahasa Sasak-Sumbawa-Bima Ditinjau dari Letak Geografisnya".
\end{abstract}

Kata Kunci: relasi kekerabatan, antarbahasa sasak-sumbawa-bima, letak geografis

\section{PENDAHULUAN}

Ilmu linguistik tidak hanya mengkaji sebuah bahasa saja, seperti bahasa Inggris, bahasa Indonesia, bahasa Jawa, bahasa Bali, bahasa Sasak, bahasa Sumbawa, atau bahasa Bima, melainkan mengkaji seluk-beluk bahasa pada umumnya, bahasa yang menjadi alat interaksi sosial milik manusia, yang dalam bahasa Prancis disebut langage.

Linguistik memperlakukan bahasa sesuai dengan perkembangan sosial budaya masyarakat pemakainya, yaitu bahasa dapat berubah dari waktu ke waktu. Karena itu pula, linguistik dapat mempelajari bahasa secara sinkronis dan diakronis. Secara sinkronik, artinya mempelajari bahasa dengan berbagai aspeknya pada kurun waktu tertentu atau terbatas. Studi sinkronis ini bersifat deskriptif, karena linguistik hanya mencoba memberikan gambaran keadaan bahasa menurut apa adanya pada kurun waktu yang terbatas. Secara diakronis, artinya mempelajari bahasa dengan 


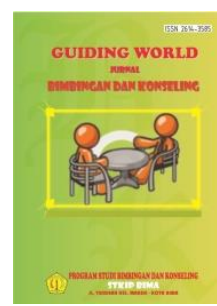

DOI: 1033627

Volume 03, Nomor 02

November 2020

E-ISSN: 2614-3585

pelbagai aspeknya dan perkembangannya dari waktu ke waktu sepanjang kehidupan bahasa itu. Studi bahasa secara diakronis ini disebut linguistik historis komparatif. Linguistik historis komparatif merupakan cabang linguistik yang mempersoalkan bahasa dalam bidang waktu serta perubahan-perubahan unsur bahasa yang terjadi pada kurun waktu tertentu serta menyelidiki perbandingan suatu bahasa dengan bahasa lain.

Penelitian linguistik historis komparatif (LHK) terhadap bahasa-bahasa di wilayah geografis Nusa Tenggara, yang meliputi Bali, NTB, dan NTT telah dilakukan oleh para ahli. Terbukti sejumlah karya tulis berupa disertasi yang menelaah sejarah bahasa-bahasa sekerabat di wilayah tersebut telah dilakukan oleh para ahli. Sejumlah karya tulis yang dimaksud antara lain karya Aron Meko Mbete (1990): Rekonstruksi Proto Bali-Sasak-Sumbawa, yang merupakan disertasi untuk Fakultas Pascasarjana Universitas Indonesia; Mahsun (1994): Rekonstuksi Proto Sasak, merupakan disertasi di bidang linguistik UGM; I Gede Budasi (2006): Kajian Linguistik Historis Komparatif terhadap Kekerabatan Bahasa-bahasa di Sumba; dan tulisan para ahli lainnya.

Terkait dengan hal tersebut, penelitian perbandingan bahasa dan pengelompokan bahasa berkerabat di wilayah geografis Nusa Tenggara termasuk bahasa-bahasa di Nusa Tenggara Barat (NTB) yang telah dilakukan para ahli menyimpulkan adanya dua pengelompokkan bahasa berkerabat, yaitu kerabat bahasa Bali-Sasak-Sumbawa dan kerabat bahasa Bima-Sumba. Terkait dengan kerabat bahasa Bima-Sumba ini berdasarkan pengelompokkan bahasa yang membagi bahasa Melayu Polinesia (Austronesia) di Indonesia kedalam 17 kelompok, satu di antaranya adalah kelompok bahasa Sumba sebagai sub-kelompok Bima-Sumba.

Penelitian bahasa-bahasa di wilayah geografis NTB yang telah ada pada umumnya masih bersifat sendiri-sendiri atau hanya meneliti pada satu bahasa saja atau bahasa-bahasa yang berkerabat saja, sedangkan penelitian ke arah perbandingan bahasa yang tidak berkerabat namun masih dalam satu wilayah geografis masih belum dilakukan secara komprehensif.

Hal ini masih perlu dilakukan penelitian yang mendalam dengan menggunakan dasar dan metode perbandingan bahasa yang tepat sehingga pengelompokkan bahasa-bahasa di NTB, termasuk bahasa Bima, akan lebih jelas posisi kekerabatan dan pengelompokkannya. Berkaitan dengan masalah tersebut, artikel ini akan membahas tentang: "Relasi Kekerabatan Antarbahasa Sasak-Sumbawa-Bima Ditinjau dari Letak Geografisnya".

Dasar pertimbangan pembahasan masalah ini karena melihat adanya persamaan isolekisolek dan dialek/subdialek yang digunakan oleh masyarakat tutur yang berada di wilayah geografis ini. Meskipun ada perbedaannya, tetapi ada ciri-cirinya yang universal

\section{KERANGKA TEORITIS DAN PENGEMBANGAN HIPOTESIS}

\section{Klasifikasi Bahasa}

Bahasa itu bersifat universal di samping juga bersifat unik. Bahasa-bahasa yang ada di dunia ini di samping ada kesamaannya ada juga perbedaannya, atau ciri khasnya masingmasing. Bahasa-bahasa di dunia ini sangat banyak; dan para penuturnya juga terdiri dari bangsa, suku bangsa, atau etnis yang berbeda-beda. Oleh karena itu, digunakan kriteria untuk membuat klasifikasi terhadap bahasa. Ada empat pendekatan yang digunakan dalam klasifikasi bahasa, yaitu: (1) pendekatan genetis, (2) pendekatan tipologis, (3) pendekatan areal, dan (4) pendekatan sosiolinguistik.

\section{a. Klasifikasi Genetis}

Klasifikasi genetis, disebut juga klasifikasi geneologis, dilakukan berdasarkan garis keturunan bahasa-bahasa itu. Artinya, suatu bahasa berasal atau diturunkan dari bahasa 


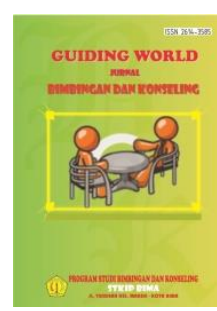

DOI: 1033627
GUIDING WORLD JURNAL

BIMBINGAN DAN KONSELING

Volume 03, Nomor 02

November 2020

E-ISSN: 2614-3585

yang lebih tua. Menurut teori klasifikasi genetis ini, suatu bahasa Proto (bahasa tua, bahasa semula) akan pecah dan menurunkan dua bahasa baru atau lebih. Lalu, bahasa pecahan ini akan menurunkan pula bahasa-bahasa lain. Kemudian bahasa-bahasa lain itu akan menurunkan lagi bahasa-bahasa pecahan berikutnya.

Penemu teori klasifikasi genetis ini adalah A. Schleicher, dan menamakannya dengan teori 'batang pohon' (bahasa Jerman: Stammbaum theorie). Teori ini dikemukakan tahun 1866, kemudian dilengkapi oleh J. Schmidt tahun 1872 dengan teori 'gelombang' (bahasa Jerman : Wellen theorie). Maksud teori gelombang ini adalah bahwa perkembangan atau perpecahan bahasa itu dapat diumpamakan seperti gelombang yang disebabkan oleh sebuah batu yang dijatuhkan ke tengah kolam. Di dekat tempat jatuhnya batu tadi akan tampak gelombang yang lebih tinggi; semakin jauh dari tempat jatuhnya batu itu gelombangnya semakin kecil atau semakin rendah dan akhirnya menghilang. Bahasa berkembang dengan cara seperti itu. Bahasa yang tersebar dekat dengan pusat penyebaran akan mempunyai ciri-ciri yang tampak jelas sama dengan bahasa induknya, tetapi yang lebih jauh ciri-cirinya akan lebih sedikit dan semakin jauh semakin sukar dilihat.

Penyebaran bahasa itu biasanya terjadi karena penuturnya menyebar atau berpindah tempat sebagai akibat adanya peperangan atau bencana alam. Kemudian karena tidak ada kontak lagi dengan tempat asalnya, maka sedikit demi sedikit bahasanya menjadi berubah. Perubahan itu dapat terjadi pada semua tataran, dari fonologi, morfologi, sintaksis, semantik, dan leksikon.

Klasifikasi genetis ini menunjukkan bahwa perkembangan bahasa-bahasa di dunia ini bersifat difergensif, yakni memecah dan menyebar menjadi banyak. Pada masa mendatang karena situasi politik dan perkembangan teknologi komunikasi yang semakin canggih, perkembangan yang konvergensif (beralihnya penggunaan bahasa asal ke bahasa yang lain) tampaknya akan lebih mungkin dapat terjadi. Kemungkinan besar akan ada bahasa-bahasa yang mati ditinggalkan para penuturnya, yang karena berbagai pertimbangan beralih menggunakan bahasa lain yang dianggap lebih menguntungkan.

\section{b. Klasifikasi Tipologis}

Klasifikasi tipologis dilakukan berdasarkan kesamaan tipe atau tipe-tipe yang terdapat pada sejumlah bahasa. Tipe ini merupakan unsur tertentu yang dapat timbul berulang-ulang dalam suatu bahasa. Unsur yang berulang-ulang ini dapat mengenai bunyi, morfem, kata, frase, kalimat, dan sebagainya. Oleh karena itu, klasifikasi tipologis ini dapat dilakukan pada semua tataran bahasa. Klasifikasi pada tataran morfologi, misalnya, telah dilakukan pada abad XIX secara garis besar dibagi tiga kelompok.

1) Kelompok pertama, adalah yang semata-mata menggunakan bentuk bahasa sebagai dasar klasifikasi. Yang mula-mula mengusulkan klasifikasi morfologi ini adalah Fredrich Von Schlegel. Dia membagi bahasa-bahasa di dunia ini pada tahun 1808 menjadi dua kelompok, yaitu (a) kelompok bahasa berafiks, dan (b) kelompok bahasa berfleksi. Pembagian ini kemudian diperluas oleh kakaknya, August Von Schlegel, pada tahun 1818 menjadi (a) bahasa tanpa struktur gramatikal (seperti bahasa Cina); (b) bahasa berafiks (seperti bahasa Turki); dan (c) bahasa berfleksi (seperti bahasa Sansekerta dan bahasa Latin).

2) Kelompok kedua, adalah yang menggunakan akar kata sebagai dasar klasifikasi. Tokohnya, antara lain, Franz Bopp, yang membagi bahasa-bahasa di dunia ini atas bahasa yang mempunyai (a) akar kata yang monosilabis, misalnya bahasa Cina; (b) akar kata yang mampu mengadakan komposisi, misalnya bahasa-bahasa Indo-Eropa 


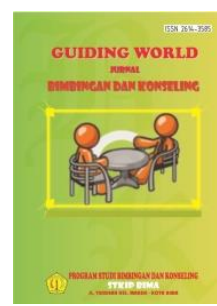

DOI: 1033627

Volume 03, Nomor 02

November 2020

E-ISSN: 2614-3585

dan bahasa Austronesia; dan (c) akar kata yang disilabis dengan tiga konsonan, seperti bahasa Arab dan Ibrani.

3) Kelompok ketiga, adalah yang menggunakan bentuk sintaksis sebagai dasar klasifikasi. Pakarnya, antara lain, H. Steinthal yang membagi bahasa-bahasa di dunia ini atas (a) bahasa-bahasa yang berbentuk, dan (b) bahasa-bahasa yang tidak berbentuk. Yang dimaksud bahasa yang berbentuk adalah bahasa yang di dalam kalimatnya terdapat relasi antarkata. Sedangkan bahasa yang tidak berbentuk adalah bahasa yang di dalam

\section{c. Klasifikasi Areal} kalimatnya tidak terlalu mengindahkan kaidah hubungan antarkata.

Klasifikasi areal dilakukan berdasarkan adanya hubungan timbal-balik antara bahasa yang satu dengan bahasa yang lain di dalam suatu areal atau wilayah, tanpa memperhatikan apakah bahasa itu berkerabat secara genetik atau tidak. Klasifikasi ini bersifat arbitrer karena dalam kontak sejarah bahasa-bahasa itu memberikan pengaruh timbal-balik dalam hal-hal tertentu yang terbatas.

Usaha klasifikasi berdasarkan areal ini pernah dilakukan oleh Wilhelm Schmidt (1868 - 1954), yang membagi bahasa berdasarkan distribusi geografis dari kelompokkelompok bahasa yang penting, disertai ciri-ciri tertentu dari bahasa-bahasa tersebut. Pada tataran fonologi Schmidt menggambarkan distribusi geografis dari bunyi-bunyi tertentu pada posisi awal dan posisi akhir. Pada tataran sintaksis dia mendeskripsikan distribusi bermacam-macam kategori dari jumlah kata benda dan kata ganti orang.

\section{d. Klasifikasi Sosiolinguistik}

Klasifikasi sosiolinguistik dilakukan berdasarkan hubungan antara faktor-faktor yang berlaku dalam masyarakat; tepatnya, berdasarkan status, fungsi, penilaian yang diberikan masyarakat terhadap bahasa. Klasifikasi sosiolinguistik ini pernah dilakukan oleh William A. Stuart tahun 1962. Klasifikasi ini dilakukan berdasarkan empat ciri atau kriteria, yaitu historisitas, standardisasi, vitalitas, dan homogenesitas.

1) Kriteria Historisitas berkenaan dengan sejarah perkembangan bahasa atau sejarah pemakaian bahasa. Kriteria historisitas akan mejadi positif kalau bahasa itu mempunyai sejarah perkembangan atau sejarah pemakaiannya.

2) Kriteria standardisasi berkenaan dengan statusnya sebagai bahasa baku atau tidak baku, atau statusnya dalam pemakaian formal atau tidak formal.

3) Kriteria Vitalitas berkenaan dengan apakah bahasa itu mempunyai penutur yang menggunakannya dalam kegiatan sehari-hari secara aktif atau tidak.

4) Kriteria homogenesitas berkenaan dengan apakah leksikon dan tata bahasa dari bahasa itu diturunkan.

\section{Dasar dan Metode Perbandingan Bahasa}

\section{a. Dasar Perbandingan Bahasa}

Tiap bahasa di dunia dapat diperbandingkan karena bahasa-bahasa tersebut memiliki ciri kesemestaan bahasa, yaitu:

1) Kesamaan bentuk dan makna.

2) Tiap bahasa memiliki perangkat unit fungsional terkecil, yaitu fonem dan morfem.

3) Tiap bahasa memiliki kelas-kelas tertentu.

Kemiripan bentuk dan makna yang terjadi dalam bahasa-bahasa dapat terjadi karena faktor sebagai berikut.

1) Warisan langsung dari bahasa proto

Ciri warisan langsung dari bahasa proto: 


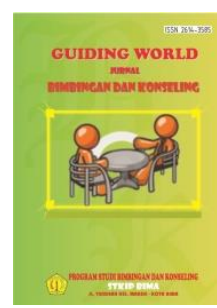

DOI: 1033627

Volume 03, Nomor 02

November 2020

E-ISSN: 2614-3585

a) Memiliki persamaan unsur kebahasaan yang meliputi kata-kata pokok, yaitu katakata yang dimiliki semua bahasa (cognate).

b) Persamaan itu relatif logis dan konsisten, misalnya dalam perubahan bunyi. Contoh bunyi [p] pada bahasa-bahasa di Eropa selatan, sedangkan dalam bahasabahasa di Eropa utara berupa bunyi [f].

2) Pinjaman

Ciri kata pinjaman berupa:

a) Kata-kata yang mengandung pengertian yang semula tidak dimiliki oleh bahasa peminjam.

b) Kata-kata yang mengandung nilai rasa tertentu; lebih sopan bila dinyatakan dengan kata pinjaman.

3) Kebetulan

Ciri persamaan karena kebetulan:

a) Penutur yang bahasanya mengandung persamaan tidak pernah berhubungan, baik fisik maupun kultural.

b) Jumlah unsur bahasa yang mengandung persamaan sangat sedikit.

Penetapan kata berkerabat berdasarkan:

1) Sejumlah besar kosakata dari suatu kelompok bahasa tertentu memperlihatkan kesamaan yang besar.

Contoh:

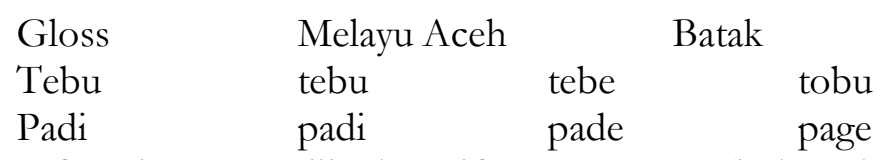

2) Perubahan fonetis memperlihatkan sifat yang teratur (hukum bunyi).

Contoh:

$\begin{array}{lll}\text { Gloss } & \text { Tagalog Bali } & \\ \text { layar } & \text { layag } & \text { layah } \\ \text { ratus } & \text { gatos } & \text { batos } \\ / \mathrm{r} />/ \mathrm{g} />/ \mathrm{h} / & \end{array}$

3) Semakin dalam menelusuri sejarah bahasa kerabat, semakin banyak ditemukan kesamaan antara pokok-pokok yang diperbandingkan.

\section{b. Metode Perbandingan Bahasa}

Linguistik historis komparatif (dalam Mahsun, 2010:60) adalah cabang dari linguistik (teoretis) yang menyelidiki perkembangan bahasa dari suatu masa ke masa yang lain, serta menyelidiki perbandingan suatu bahasa dengan bahasa lain. Menurut Mahsun (2010:60-61), ada dua objek kajian yang dapat dilakukan dalam menyelidiki perbandingan suatu bahasa dengan bahasa lain, yaitu:

1) Objek kajiannya difokuskan pada satu bahasa tertentu, namun penelaahannya difokuskan pada deskripsi perbedaan bahasa itu dari suatu kurun waktu tertentu ke kurun waktu yang lain. Misalnya perbandingan bahasa Indonesia pada masa sebelum kemerdekaan dengan bahasa Indonesia era reformasi.

2) Objek kajiannya difokuskan pada lebih dari satu bahasa, yang tujuannya untuk menentukan relasi kekerabatan yang terdapat di antara bahasa-bahasa tersebut.

Garapan kajian perbandingan bahasa (linguistik historis komparatif) menurut Mahsun (2010:62) mencakup hal-hal berikut ini.

1) Penentuan status isolek sebagai bahasa, 


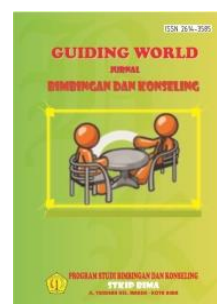

DOI: 1033627

Volume 03, Nomor 02

November 2020

E-ISSN: 2614-3585

2) Penentuan hubungan kekerabatan dan pengelompokkan bahasa,

3) Rekonstruksi bahasa purba, dan

4) Penentuan pusat persebaran bahasa.

Selanjutnya, Mahsun (2010:63-64) menjelaskan bahwa langkah pertama yang harus dilakukan dalam kerja linguistik historis komparatif adalah memastikan bahwa isolek yang akan diperbandingkan itu adalah memang benar berstatus bahasa, bukan dialek atau level di bawahnya. Kemudian penentuan status bahasa dilakukan serempak dengan penentuan hubungan kekerabatan atau pengelompokkan bahasa melalui penerapan leksikostatistik, yang selanjutnya berdasarkan pengelompokkan itulah ditentukan evidensi bahasa pada cabang manakah yang akan dijadikan bukti untuk melakukan rekonstruksi bahasa purbanya. Melalui perbandingan bahasa purba pada level prabahasa itulah akan diperoleh hasil rekonstruksi bahasa purba pada level protobahasa yang dapat dipertanggungjawabkan secara ilmiah.

1) Metode Leksikostatistik

Metode leksikostatistik adalah metode pengelompokkan bahasa yang dilakukan dengan menghitung persentase perangkat kata berkerabat (kognat). Kosa kata yang menjadi dasar penghitungan adalah kosa kata dasar (basic vocabulary).

Penerapan metode leksikostatistik bertumpu pada tiga asumsi dasar, yaitu:

a) Sebagian dari kosa kata dalam suatu bahasa sukar sekali berubah dibandingkan dengan bagian lainnya.

b) Retensi atau ketahanan kosa kata dasar adalah konstan sepanjang masa.

c) Perubahan yang terjadi pada semua kata dalam kosa kata dasar dalam suatu bahasa adalah sama (dalam Mahsun, 2010:65).

Dalam penelitian linguistik historis komparatif metode leksikostatistik ini dapat digunakan untuk mengelompokkan beberapa daerah pengamatan sebagai kelompok pemakai bahasa yang sama atau pemakai bahasa yang berbeda dengan menghitung persentase kata berkerabat antardaerah pengamatan.

Leksikostatistik tidak diperuntukkan bagi penentuan status isolek sebagai dialek atau subdialek, tetapi lebih sebagai metode untuk menentukan daerah pengamatan atau daerah pengamatan sebagai pemakai bahasa yang sama atau sebagai pemakai bahasa yang berbeda, yang dapat sebagai keluarga (family), rumpun (stock), mikrofilum, messofilum, atau makrofilum. Dengan kata lain, metode leksikostatistik lebih ditujukan sebagai metode kuantitatif yang digunakan untuk pengelompokkan bahasa.

Untuk melakukan penghitungan leksikostatistik adalah mengumpulkan kosa kata dasar bahasa yang berkerabat yang dilakukan melalui metode cakap (wawancara) dengan berpedoman pada daftar pertanyaan yang berupa kosa kata dasar. Setelah kosa kata dasar dalam beberapa bahasa yang diperbandingkan itu diperoleh kemudian dilakukan penghitungan jumlah kosa kata yang berkerabat.

2) Metode Kesamaan Ciri-ciri Linguistik

Metode kesamaan ciri-ciri linguistik selain dijadikan dasar penentuan status isolek sebagai bahasa, dialek, subdialek, tetapi juga dapat digunakan untuk penentuan kekerabatan dan pengelompokkan dialek/subdialek dan bahasa secara kualitatif.

Ada dua wujud ciri kesamaan linguistik yang dapat dijadikan dasar penentuan status isolek, yaitu retensi dan inovasi bersama. Metode inovasi bersama adalah cara pengelompokkan bahasa turunan ke dalam suatu kelompok yang lebih dekat hubungannya, karena memperlihatkan inovasi yang berciri linguistik ekslusif yang 


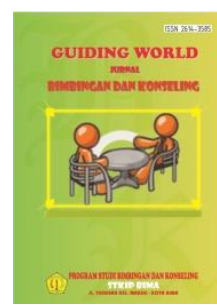

DOI: 1033627

Volume 03, Nomor 02

November 2020

E-ISSN: 2614-3585

menyebar pada bahasa-bahasa yang diperbandingkan. Metode ini dapat dipertanggungjawabkan apabila bahasa yang diperbandingkan memperlihatkan inovasi bersama itu berjauhan letaknya, sehingga kesamaan inovasi yang secara ekslusif itu bukan sebagai hasil pinjaman atau pengaruh mempengaruhi satu sama lain.

Metode inovasi bersama ini dapat juga diterapkan pada penentuan hubungan kedekatan antardialek yang ada dalam satu bahasa. Inovasi bersama tidak hanya terjadi pada tataran leksikal, tetapi dapat juga terjadi pada tataran linguistik lainnya, seperti tataran fonologis, morfologis, sintaksis, dan semantik

\section{METODE}

Kajian perbandingan bahasa dalam pembahasan ini didasarkan pada teori Mahsun, yaitu pertama penentuan status isolek sebagai bahasa. Dalam mengkaji perbedaan-perbedaan isolek (alat komunikasi suatu masyarakat tutur namun belum ditetapkan statusnya) dengan memperlakukan perbedaan-perbedaan tersebut secara utuh.

Kedua, penentuan hubungan kekerabatan dan pengelompokkan bahasa. Dalam penentuan hubungan kekerabatan dan pengelompokkan bahasa ini didasarkan pada penghitungan leksikostatistik, sebagaimana yang digambarkan dalam tabel berikut ini.

\begin{tabular}{|c|c|c|}
\hline Tingkat Bahasa & $\begin{array}{c}\text { Waktu Pisah (time depth) } \\
\text { dalam Abad }\end{array}$ & $\begin{array}{c}\text { Persentase Kata } \\
\text { Kerabat }\end{array}$ \\
\hline Bahasa (Language) & $0-5$ & $100-81$ \\
\hline Keluarga (Family) & $5-25$ & $81-36$ \\
\hline Rumpun (Stock) & $25-50$ & $36-12$ \\
\hline Mikrofilum & $50-75$ & $12-4$ \\
\hline Mesofilum & $75-100$ & $4-1$ \\
\hline Makrofilum & 100 ke atas & 1- kurang dari 1 \\
\hline
\end{tabular}

Ketiga, rekonstruksi bahasa purba dengan cara membuat rekonstruksi prabahasa yang diteliti dengan memanfaatkan evidensi (bahan) yang terdapat dalam dialek. Selanjutnya, membuat analisis dialek atau subdialek ke dalam dialek atau subdialek relik (dialek yang banyak mempertahankan bentuk kuno) dan dialek atau subdialek pembaharu.

Keempat, penentuan pusat persebaran bahasa dengan cara:

1) Menelusuri pengaruh antardialek atau subdialek yang diteliti serta situasi persebaran geografisnya,

2) Menelusuri unsur kebahasaan yang merupakan inovasi (unsur baru) serta situasi persebarannya pada tiap dialek atau subdialek,

3) Menelusuri unsur kebahasaan yang merupakan bentuk relik (pewarisan bahasa) pada dialek atau subdialek serta persebaran geografisnya,

Menelusuri saling hubungan antara unsur-unsur kebahasaan yang berbeda diantara dialek atau subdialek yang diteliti. 


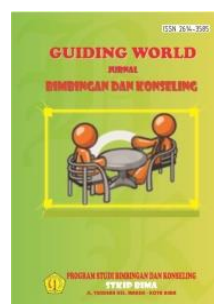

DOI: 1033627

Volume 03, Nomor 02

November 2020

E-ISSN: 2614-3585

\section{HASIL PENELITIAN DAN PEMBAHASAN}

Dalam menganalisis perbandingan bahasa perlu dilihat kaitan antara dialektologi dengan kajian linguistik historis komparatif. Dialektologi merupakan puncak perkembangan dari kajian linguistik historis komparatif. Dialektologi banyak memanfaatkan metode linguistik historis komparatif, seperti rekonstruksi dan penelusuran inovasi seperti yang dideskripsikan dalam tabel berikut ini.

\begin{tabular}{|c|c|}
\hline Dialektologi Diakronis & Linguistik Historis Komparatif \\
\hline Mencari perbedaan & Mencari persamaan \\
\hline $\begin{array}{c}\text { Merekonstruksi prabahasa pada dialek atau } \\
\text { subdialek }\end{array}$ & Merekonstruksi bahasa proto \\
\hline $\begin{array}{c}\text { Rekonstruksi didasarkan pada evidensi } \\
\text { (bahan) dialek atau subdialek }\end{array}$ & $\begin{array}{c}\text { Rekonstruksi didasarkan pada } \\
\text { evidensi (bahan) bahasa }\end{array}$ \\
\hline
\end{tabular}

Selain kaitannya dengan dialektologi, linguistik historis komparatif juga dihubungkan dengan sosiolinguistik. Jika dialektologi mempelajari perbedaan unsur-unsur kebahasaan yang terdapat dalam satu bahasa yang disebabkan faktor geografis (diatopik), maka sosiolinguistik mempelajari perbedaan unsur-unsur kebahasaan yang disebabkan faktor sosial meliputi tempat, situasi, penutur, usia, pendidikan, dan lain lain.

Dalam kaitannya dengan geografi, linguistik historis komparatif memanfaatkan ilmu geografi untuk memetakan kondisi kebahasaan yang terdapat di daerah titik pengamatan. Fungsi dari pemetaan ini untuk menvisualisasikan letak geografis yang menjadi tempat digunakan suatu bentuk bahasa tertentu. Sedangkan kaitannya dengan sejarah, yaitu munculnya perbedaan unsur-unsur kebahasaan dalam suatu bahasa sehingga memunculkan perbedaan dialek atau subdialek terjadi dalam fase perkembangan yang dialami penutur bahasa tersebut. Sumbangan yang diberikan ilmu sejarah pada kajian perbandingan bahasa berkaitan dengan penentuan bentuk yang digunakan sebagai pinjaman atau bentuk asli.

Relasi kekerabatan antarbahasa sekerabat ditinjau dari letak geografisnya, seperti bahasa Sasak-Sumbawa-Bima, yang dalam kajian komparatif pada intinya dapat dibuktikan berdasarkan unsur-unsur warisan dari protobahasa pada bahasa-bahasa berkerabat tersebut. Protobahasa sesungguhnya bukanlah wujud nyata bahasa, melainkan suatu bangunan bahasa yang dirakit secara teoretis hipotetis (Mbete dalam Budasi, 2006:6).

Protobahasa merupakan suatu rakitan teoretis yang dirancang dengan cara merangkaikan sistem bahasa-bahasa yang memiliki hubungan kesejarahan, melalui rumusan kaidah-kaidah secara sangat sederhana dan dirancang bangun dan dirakit kembali sebagai gambaran tentang masa lalu suatu bahasa. Dengan munculnya ciri-ciri warisan yang sama pada bahasa-bahasa yang berkerabat, keeratan hubungan keseasalan bahasa-bahasa tersebut dapat ditemukan dan sistem protobahasanya dapat dijejaki (Mbete dalam Budasi, 2006:7).

Upaya pengelompokan isolek-isolek atau bahasa-bahasa berkerabat seperti bahasa Sasak-Sumbawa-Bima berarti suatu upaya menempatkan isoslek-isolek atau bahasa-bahasa berkerabat tersebut agar jelas struktur kekerabatannya atau struktur genetisnya. Dengan demikian, kejelasan kedudukan antara bahasa Bima dengan bahasa Sasak dan Sumbawa yang berkerabat dapat diketahui. Di lain pihak, rekonstruksi protobahasa dari sekelompok bahasa yang diduga berkerabat di samping merupakan upaya mengadakan pengelompokan bahasa 


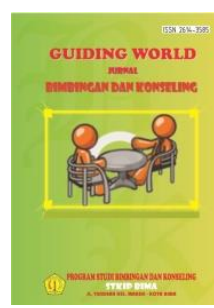

DOI: 1033627

Volume 03, Nomor 02

November 2020

E-ISSN: 2614-3585

juga memperjelas hubungan kekerabatan dan ikatan keasalan dari bahasa-bahasa berkerabat tersebut, terutama dari sisi rekurensi kesepadanan (korespondensi) fonem pada kata yang memiliki makna berkaitan.

Berkaitan dengan penjelasan di atas, berikut ini dideskripsikan perbandingan kosa kata bahasa Sasak-Sumbawa-Bima yang menjadi pembahasan artikel ini: apakah bahasa Bima berkerabat dengan bahasa Sasak-Sumbawa? Kosa kata yang menjadi dasar perbandingan adalah kosa kata dasar (basic vocabulary).

DAFTAR KOSAKATA SWADESH (REVISI BLUST, 1980)

\section{NO. GLOSS}

BHS. SUMBAWA

BHS. SASAK

BHS. BIMA

\begin{tabular}{|c|c|c|c|c|}
\hline 1 & tangan & Ima & Ima & Rima \\
\hline 2 & kiri & Kidal & Kiri & ku’i \\
\hline 3 & kanan & Kanan & Kanan & Wana \\
\hline 4 & kaki & $\mathrm{Ne}$ & $\mathrm{Nae}$ & Edi \\
\hline 5 & berjalan & Belangan & lampaq uah & Lampana \\
\hline 6 & jalan & Ola & Lampaq & Lampa \\
\hline 7 & datang & Dating & Dating & Mai \\
\hline 8 & belok & Mengko & Belok & Peko \\
\hline 9 & berenang & Nange & Berenang & Liwa \\
\hline 10 & kotor & Lesek & Lesek & Sampu \\
\hline 11 & debu & Awu & Debu & Kalububu \\
\hline 12 & kulit & Lukit & Kulit & Huri \\
\hline 13 & punggung & Bangkang & Punggung & Kontu \\
\hline 14 & perut & Tian & Tian & Loko \\
\hline 15 & tulang & Tolang & Tulang & Peke \\
\hline 16 & usus & Taleko & Usus & Loko \\
\hline 17 & hati & Ate & Ate & Ade \\
\hline 18 & susu & Susu & Susu & Susu \\
\hline 19 & bahu & Toak & Bahu & $\underline{\text { Dinca }}$ \\
\hline 20 & tahu & To & Taoi & $\underline{B} a d e$ \\
\hline 21 & berpikir & Mikir & Mikir & Kananu \\
\hline 22 & takut & Taket & Takut & Dahu \\
\hline 23 & darah & Geti & Daraq & ra'a \\
\hline 24 & kepala & Otak & Otak & Tuta \\
\hline 25 & leher & Korok & Leher & wo'o \\
\hline 26 & rambut & Bulu & Bulu & Honggo \\
\hline 27 & hidung & Idung & Hidung & Ilu \\
\hline 28 & bernapas & Beriak & Bernapas & Sasinawa \\
\hline 29 & mencium & Iduk & Siduk & Sangufi \\
\hline
\end{tabular}




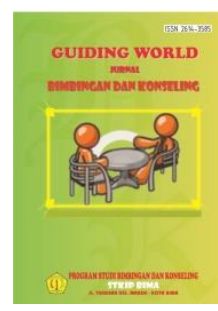

DOI: 1033627

Volume 03, Nomor 02

November 2020

E-ISSN: 2614-3585

mulut

Boa

31 gigi

32 lidah

33 tertawa

34 menangis

35 muntah

36 meludah

37 makan

38 mengunyah

39 memasak

40 minum

41 mengigit

42 mengisap

43 telinga

44 mendengar

45 mata

46 melihat

47 menguap

48 tidur

49 berbaring

50 bermimpi

51 duduk

52 berdiri

53 orang

54 laki-laki

55 perempuan

56 anak

57 suami

58 istri

59 ibu

60 bapak

61 rumah

62 atap

63 nama

64 berkata

65 tali

66 mengikat
Iset

Ela

Ketawa

Nangis

Nguta

Betisu

Mangan

Ngame

Bejampang

Inum

Ngeset

Adis

Kuping

Menong

Mata

Gita

Ngantok

Tunung

Ngulang

Beripi

Tokal

Manang

Tau

Slaki

Swai

Anak

Selaki

Soai

Ina

Bapak

Bale

Atap

Singen

Beling

Tali

Tali
Mulut

Gigi

Lidah

Ngerereq

Nangis

Nguta

Betisu

Ngelor

Ngunyah

Masak

Nginum

Ngeset

Sedot

Kentok

Bedengah

Mate

Begita

Nguap

Tindoak

tindoq-tindoqan

Ngimpi

Tokol

Nganjeng

Dengan

Mame

Nine

Anak

Semame

Senime

Inaq

Ama

Bale

Atap

Aran

Ngeraos

Tali

Ngiket
Asa

Woi

Lera

Hari

Nangi

Lohi

Katufe

Ngaha

Mama

Mbako

Nono

Ngenge

Hinti

Fiko

ringa, kade'e

Mada

Eda

Mawa

Maru

Ndore

Nifi

Doho

Kidi

Dou

Mone

Siwe

Ana

Rahi

Wei

Ina

Ama

Uma

Butu

Ngara

Nuntu

Ai

Diki 


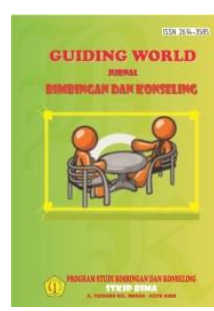

DOI: 1033627

Volume 03, Nomor 02

November 2020

E-ISSN: 2614-3585

\begin{tabular}{|c|c|c|c|}
\hline menjahit & Ngejit & Jahit & nda'u \\
\hline jarum & Jarem & Jarum & nda'u \\
\hline berburu & Ngayang & Berburu & Nggalo \\
\hline menembak & Temak & Tembak & Bedi \\
\hline menikam & Goco & Tusuk & Tuba \\
\hline memukul & Pukel & Ngempuk & Boe \\
\hline mencuri & Nyoro & Maling & Mpanga \\
\hline membunuh & Samete & Mateq & Hade \\
\hline mati & Mate & Mate & Made \\
\hline hidup & Telas & Hidup & Mori \\
\hline menggaruk & Kerok & Garuk & $\mathrm{KaO}$ \\
\hline memotong & Tetak & Meleng & Dompo \\
\hline kayu & Kayu & Kayu & Haju \\
\hline membela & Bela & Belah & Bela \\
\hline tajam & Tayam & Tajem & Ngaha \\
\hline tumpul & Tumpel & Tumpul & Dampa \\
\hline bekerja & enti boat & Begawean & Karawi \\
\hline menanam & Tanam & Nanem & Ngguda \\
\hline memilih & Pilih & Mileq & Kadale \\
\hline bertumbuh & Tumung & Tumbuh & Woko \\
\hline bengkak & Bara & Bengkak & Winte \\
\hline memeras & Pera & Peras & Pua \\
\hline memegang & Enti & Demak & Nenti \\
\hline menggali & Kali & Gali & Ngari \\
\hline membeli & Beli & Bayah & Weli \\
\hline membuka & Buka & Buka & Hengga \\
\hline mengetuk & Ketok & Ketok & Toke \\
\hline melempar & Palentong & Teteh & Bale \\
\hline jatuh & Teri & Teri & Mabuu \\
\hline anjing & Asu & Acong & Lako \\
\hline burung & Piyo & Burung & Nasi (peo?) \\
\hline ayam & Ayam & Manuk & Janga \\
\hline telur & Tele & Telok & Dolu \\
\hline bulu & Bulu & Bulu & Kere \\
\hline sayap & Kaletek & Sayap & Kalete \\
\hline terbang & Ngibar & Kelep & Ngemo \\
\hline tikus & Tikes & Begang & Karawo \\
\hline
\end{tabular}




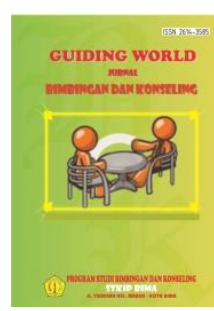

DOI: 1033627

Volume 03, Nomor 02

November 2020

E-ISSN: 2614-3585

\begin{tabular}{|c|c|c|c|c|}
\hline 104 & daging & Daging & Daging & hi'i \\
\hline 105 & lemak & Uwer & Lemak & Apa \\
\hline 106 & ekor & Elong & Elong & Keto \\
\hline 107 & ular & Bele & Ulah & rae, sawa \\
\hline 108 & cacing & Belati & Ulat & Koli \\
\hline 109 & kutu & Gutu & Gutu & Hudu \\
\hline 110 & nyamuk & Rengit & Brangkak & Karoku \\
\hline 111 & laba-laba & Kengkang & laba-laba & Cakarawa \\
\hline 112 & ikan & Jangan & Empaq & Uta \\
\hline 113 & busuk & Baong & Busuk & Mbai \\
\hline 114 & batang & Batang & Batang & Tako \\
\hline 115 & daun & Godong & Daun & ro’o \\
\hline 116 & akar & Akar & Akah & Amu \\
\hline 117 & bunga & Kemang & Bunga & Wunta \\
\hline 118 & buah & Bua & Buah & Wua \\
\hline 119 & rumput & Rebu & Rumput & Mpori \\
\hline 120 & $\tan a h$ & Tana & Tanah & Dana \\
\hline 121 & batu & Batu & Batu & Wadu \\
\hline 122 & pasir & Gersik & Pasir & Sarae \\
\hline 123 & air & $\mathrm{Ai}$ & $\mathrm{Ai}$ & Oi \\
\hline 124 & mengalir & Berereng & Ngalir & rai oi \\
\hline 125 & laut & Let & Pesisi & Moti \\
\hline 126 & garam & Sira & Garam & Sia \\
\hline 127 & danau & Lebo & Danau & Diwu \\
\hline 128 & hutan & Tua & Hutan & Wuba \\
\hline 129 & langit & Langit & Langit & Langi \\
\hline 130 & bulan & Bulan & Bulan & Wura \\
\hline 131 & bintang & Bintang & Bintang & Ntara \\
\hline 132 & awan & Awan & Awan & Apu \\
\hline 133 & kabut & Rembin & Kabut & Apu \\
\hline 134 & hujan & Ujan & Ujan & Ura \\
\hline 135 & guntur & Gunter & Guntur & Karimbimbo \\
\hline 136 & kilat & Gelap & Kilat & kakila ai \\
\hline 137 & angin & Angin & Angin & Angi \\
\hline 138 & meniup & Tiup & Tiup & Ufi \\
\hline 139 & panas & Panas & Panas & Pana \\
\hline 140 & dingin & Dingin & Nyet & $\underline{B u s i}$ \\
\hline
\end{tabular}




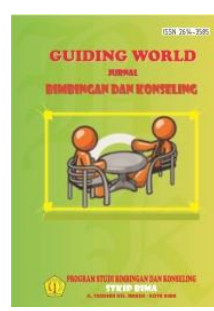

DOI: 1033627

Volume 03, Nomor 02

November 2020

E-ISSN: 2614-3585

\begin{tabular}{|c|c|c|c|}
\hline 141 kering & Toar & Kering & Mango \\
\hline basah & Basa & Kopek & Mbeca \\
\hline berat & Berat & Berat & Tani \\
\hline api & Api & Api & Afi \\
\hline membakar & Tunung & Sedut & ka'a \\
\hline asap & Penat & Asap & $\mathrm{O} \underline{b} u$ \\
\hline $\mathrm{abu}$ & $\mathrm{Au}$ & Abu & Kalubu \\
\hline hitam & Pisak & Item & me'e \\
\hline putih & Puti & Pute & $\underline{B u r a}$ \\
\hline merah & Mira & Bea & Kala \\
\hline kuning & Kuning & Kuning & Monca \\
\hline hijau & Ijo & Ijo & $\mathrm{JaO}$ \\
\hline kecil & Ode & Kecet & to’i \\
\hline besar & Rea & Beleq & na'e \\
\hline pendek & Pene & kerdil/ boncel & Poro \\
\hline panjang & Belo & Belok & Naru \\
\hline tipis & Tipis & Tipis & Nipi \\
\hline tebal & Tebal & Tebel & Tebe \\
\hline sempit & Sekat & Sempit & seke, tuka \\
\hline lebar & Lebar & Lebar & Paja \\
\hline sakit & Ngering & Sakit & pili, hengge \\
\hline malu & Kangila & Malu & Maja \\
\hline tua & Loka & Toaq & Tua \\
\hline baru & Bru & Baru & $\underline{B}$ ou \\
\hline baik & Balong & Baik & Taho \\
\hline jahat & Jahat & Jahat & Dabae \\
\hline benar & Betul & Bener & Ncihi \\
\hline malam & Petang & Petang & Amangadi \\
\hline hari & Ano & Jelo & Ainain \\
\hline tahun & Ten & Taun & mba'a \\
\hline kapan & Pidan & Piran & bune ai \\
\hline sembunyi & Besio & Sebuk & Ncimi \\
\hline naik & Ntek & Taek & Teka \\
\hline di & Pang & Lek & $\underline{\mathrm{Di}}$ \\
\hline di dalam & pang dalam & lek dalam & Tadei \\
\hline di atas & pang bao & lek atas & Taese \\
\hline di bawah & pang bawa & lek bawah & Taawa \\
\hline
\end{tabular}




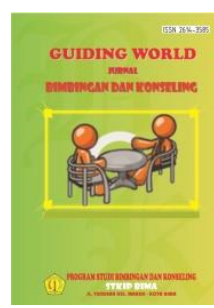

DOI: 1033627

Volume 03, Nomor 02

November 2020

E-ISSN: 2614-3585

\begin{tabular}{|c|c|c|c|}
\hline 178 ini & Deta & $\mathrm{Ne}$ & Ake \\
\hline 179 & Deto & Eno & Ede \\
\hline jauh & Do & Jaoq & do’o \\
\hline dekat & Parak & Deket & Deni \\
\hline di mana & Mepang & lek embe & Tabe \\
\hline saya & Kaji & aku/ tiang & nahu, mada \\
\hline kamu, engkau & Kau & side, engkau & nggomi, ndaim \\
\hline kita, kami & Kita & kite, ite-ite & Ndai \\
\hline dia & Nya & Kamu & Sia \\
\hline mereka & & Selapu & Siadoho \\
\hline apa & Apa & Apa & $\mathrm{Au}$ \\
\hline siapa & Sai & Sai & Cou \\
\hline lain & Len & Lain & Makalai \\
\hline semua & Sarea & Selapu & sara’a \\
\hline dan, engkau & $\mathrm{Ke}$ & dan, dengan & ro nggomi \\
\hline jika & Missal & Jika & nggira ndede \\
\hline bagaimana & Memluk & Berembe & Bune \\
\hline tidak & No & Endeq & Wati \\
\hline hitung & Itung & Hitung & Reke \\
\hline satu & sopo, seke, sai & Seke & Ica \\
\hline dua & Dua & Dua & $\underline{\text { Dua }}$ \\
\hline tiga & Telu & Telu & Tolu \\
\hline empat & Empat & Empat & Upa \\
\hline
\end{tabular}

Daftar kosakata di atas menunjukkan adanya kesamaan ciri-ciri linguistik pada beberapa kosakata dasar sebagaimana dideskripsikan dalam tabel berikut.

\begin{tabular}{|c|l|l|l|l|}
\hline No & \multicolumn{1}{|c|}{ Gloss } & \multicolumn{1}{|c|}{ Bhs Sasak } & \multicolumn{1}{|c|}{ Bhs Sumbawa } & \multicolumn{1}{c|}{ Bhs Bima } \\
\hline 1 & tangan & Ima & Ima & Rima \\
\hline 2 & mengigit & Ngeset & Ngeset & Ngenge \\
\hline 3 & buah & Buah & Bua & Wua \\
\hline 4 & tanah & Tanah & Tana & Dana \\
\hline 5 & batu & Batu & Batu & Wadu \\
\hline 6 & langit & Langit & Langit & Langi \\
\hline 7 & hati & Ate & Ate & Ade \\
\hline 8 & susu & Susu & Susu & Susu \\
\hline 9 & menangis & Nangis & Nangis & Nangi \\
\hline 10 & anak & Anak & Anak & Ana \\
\hline 11 & ibu & Inaq & Ina & Ina \\
\hline 12 & bapak & Amaq & Bapak & Ama \\
\hline
\end{tabular}




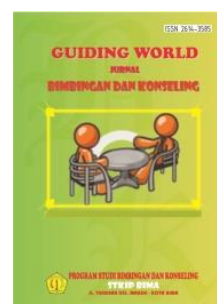

DOI: 1033627

Volume 03, Nomor 02

November 2020

E-ISSN: 2614-3585

\begin{tabular}{|l|l|l|l|l|}
\hline 13 & nama & Aran & Singen & Ngara \\
\hline 14 & mati & Mate & Mate & Made \\
\hline 15 & membela & Belah & Bela & Bela \\
\hline 16 & memegang & Demak & Enti & Nenti \\
\hline 17 & sayap & Sayap & Kaletek & Kalete \\
\hline 18 & garam & Garam & Sira & Sia \\
\hline 19 & angin & Angin & Angin & Angi \\
\hline 20 & api & Api & Api & Afi \\
\hline 21 & tebal & Tebel & Tebal & Tebe \\
\hline 22 & dua & Dua & Dua & $\underline{\text { Dua }}$ \\
\hline 23 & tiga & Telu & Telu & Tolu \\
\hline
\end{tabular}

Berdasarkan deskripsi di atas, maka kesamaan ciri-ciri linguistik pada bahasa SasakSumbawa-Bima kebanyakan pada bentuk kata pinjaman secara sosiolinguistik, bukan karena faktor genetisnya. Sebab, suatu pengelompokan genetis adalah suatu hipotesis tentang perkembangan sejarah bahasa-bahasa yang dibandingkan karena pengelompokan genetis menjelaskan kesamaan dan kemiripan yang dapat diamati yang berkaitan dengan ciri-ciri induk atau protobahasa yang menurunkan bahasa sekarang.

Asumsi yang mendasari hipotesis ini, yaitu jika kondisi hubungan antarbahasa yang diperbandingkan adalah wajar (normal), maka isolek-isolek atau bahasa-bahasa itu berasal dari satu induk bahasa, dan hubungan antara isolek atau bahasa itu dapat dinyatakan dalam suatu silsilah kekerabatan (a family tree) yang menggambarkan urutan bahasa masa kini dari masa perkembangan sejarah bahasa sebelumnya secara berturut-turut.

Dengan demikian, protobahasa sebagai suatu sistem yang diabstraksikan dari wujud bahasa-bahasa berkerabat merupakan pantulan kesejarahan bahwa bahasa-bahasa itu pernah mengalami perkembangan yang sama sebagai bahasa-bahasa tunggal. Paling tidak terdapat dua pijakan hipotesis dalam merekonstruksi protobahasa: Hipotesis keterhubungan dan hipotesis keteraturan.

Hipotesis yang pertama memiliki ciri kemiripan dan kesamaan wujud kebahasaan. Salah satu kemiripan bentuk yang diandalkan adalah kemiripan bentuk dan makna kata-kata. Kata-kata yang memilki kemiripan atau kesamaan bentuk dan makna yang biasa disebut kosakata seasal (cognate set). Kata-kata ini bukan sebagai pinjaman, kebetulan, atau kecendrungan semesta, melainkan sebagai warisan dari asal-usul yang sama. Hipotesis yang kedua, hipotesis keteraturan, berwujud perubahan bunyi yang bersistem dan teratur pada bahasa-bahasa turunan. Dengan kata lain, perubahan bunyi yang teratur pada kosakata dari bahasa-bahasa berkerabat merupakan ciri-ciri warisan dari bunyi protobahasanya.

Inti persoalan dalam kegiatan penelusuran hubungan tingkat kekerabatan suatu bahasa ditinjau dari usaha pengelompokan maupun rekonstruksi adalah perolehan buktibukti yang meyakinkan, baik secara kuantitatif maupun bukti secara kualitatif. Bukti kuantitatif dapat berupa sejumlah kata kerabat yang berkaitan dengan retensi bersama. Sedangkan bukti kualitatif dapat berupa korespondensi fonologis dan inovasi bersama.

Dalam hal penjejakan bukti kuantitatif, fakta-fakta kebahasaan yang biasanya diangkat dalam rangka pembuktian hubungan kekerabatan bahasa-bahasa berkerabat sebagai satu kelompok atau subkelompok tersendiri merupakan gejala penyimpangan atau retensi, khususnya retensi kata. Dalam linguistik historis komparatif kajian yang menyangkut retensi 


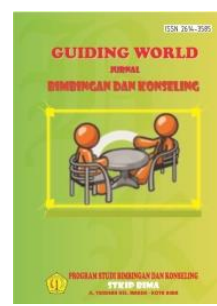

kata-kata, tergolong dalam kajian yangberdasarkan pendekatan kuantitatif. Dalam pendekatan kuantitatif ini, biasanya dilakukan perbandingan terhadap sejumlah bahasa kerabat melalui kosakata dasarnya.

Perangkat kata dasar yang dipergunakan dalam studi semacam ini memanfaatkan daftar kata yang oleh ahli-ahli bahasa dipercaya memiliki sifat universal. Penelaahan dalam pendekatan kuantitatif ini menggunakan metode leksikostatistik di mana bukti-bukti kuantitatif dipakai sebagai dasar pengelompokan tahap awal dari suatu bahasa untuk tujuan pemerolehan persentase kosakata. Metode ini bertolak dari suatu asumsi bahwa perbendaharaan kata dalam suatu bahasa dapat dibedakan dalam dua kelompok yang besar (dalam Budasi, 2006:11) :

a. Kata-kata yang tidak gampang berubah, misalnya kata mengenai anggota tubuh, kata ganti, kata-kata yang menyatakan perasaan, kata-kata yang bertalian dengan cuaca dan alam, kata-kata bilangan, dan kata-kata yang berhubungan dengan perlengkapan rumah tangga yang dianggap ada sejak permulaan. Semua kata ini dimasukkan dalam sebuah kelompok yang disebut kata dasar.

b. Kata-kata yang mudah berubah, yaitu kata-kata yang dipinjamkan kepada atau dari kebudayaan lain. Misalnya kata-kata meja, kursi, baju, lampu. Kata-kata ini mudah mengalami difusi (pengaruh migrasi dan pengalihan pranata budaya melewati batas-batas bahasa, khususnya inovasi dan peminjaman).

Pada tingkat selanjunya adalah menghitung masa pisah setiap bahasa dengan menggunakan glotokronologis (Mbete dalam Budasi, 2006:11), sedangkan asumsi yang mendasari adalah harkat pengikisan (retensi) seperangkat kata bersifat semesta dan konstan sepanjang masa.

Ada beberapa pendapat mengenai kisaran persentase perubahan kosakata kerabat yang berkaitan dengan retensi bersama. Swadesh (1952), Hockett (1963), dan Dyen (1975) mengemukakan perubahan kosakata tersebut umumnya mencapai antara $19 \%$ dalam setiap seribu tahun atau mampu bertahan antara $81 \%$; Crowley (1983) berpendapat $80 \%$, sedangkan Keraf (1984) berpendapat 80,5 \% (dalam Budasi, 2006:11-12).

berikut:

Berdasarkan paparan tersebut di atas, secara singkat dapat disimpulkan sebagai

a. Baik bukti kuantitatif maupun bukti kualitatif, dapat digunakan untuk mengelompokkan bahasa-bahasa yang diperbandingkan.

Pendekatan yang bersifat kuantitatif memanfaatkan segi kebahasaan yang statis dengan landasan teoretis tentang adanya unsur-unsur kebahasaan

\section{PENUTUP}

1. Dasar perbandingan bahasa adalah karena bahasa memiliki ciri kesemestaan, yaitu: (a) Kesamaan bentuk dan makna; (b) Tiap bahasa memiliki perangkat unit fungsional terkecil, yaitu fonem dan morfem; (c) Tiap bahasa memiliki kelas-kelas tertentu.

2. Kajian perbandingan bahasa dalam pembahasan ini didasarkan pada teori Mahsun, yaitu: (a) Penentuan status isolek sebagai bahasa; (b) Penentuan hubungan kekerabatan dan pengelompokkan bahasa; (c) Rekonstruksi bahasa purba; dan (d) Penentuan pusat persebaran bahasa.

3. Metode yang digunakan dalam analisis perbandingan bahasa ini menggunakan metode leksikostatistik dan kesamaan ciri-ciri linguistik. Metode leksikostatistik lebih ditujukan sebagai 


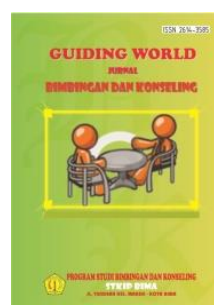

DOI: 1033627

Volume 03, Nomor 02

November 2020

E-ISSN: 2614-3585

metode kuantitatif yang digunakan untuk pengelompokkan bahasa. Metode leksikostatistik ini dapat digunakan untuk mengelompokkan beberapa daerah pengamatan sebagai kelompok pemakai bahasa yang sama atau pemakai bahasa yang berbeda dengan menghitung persentase kata berkerabat antardaerah pengamatan. Sedangkan metode kesamaan ciri-ciri linguistik selain dijadikan dasar penentuan status isolek sebagai bahasa, tetapi juga dapat digunakan untuk penentuan kekerabatan dan pengelompokkan dialek/subdialek.

4. Hipotesis yang digunakan dalam merekonstruksi protobahasa (bahasa induk), yaitu hipotesis keterhubungan dan hipotesis keteraturan. Hipotesis keterhubungan, yaitu dengan mengamati ciri kemiripan dan kesamaan wujud kebahasaan. Salah satu kemiripan bentuk yang diandalkan adalah kemiripan bentuk dan makna kata-kata. Kata-kata ini bukan sebagai pinjaman atau kebetulan, melainkan sebagai warisan dari asal-usul yang sama. Sedangkan hipotesis keteraturan dengan mengamati wujud perubahan bunyi yang bersistem dan teratur pada bahasa-bahasa turunan. Dengan kata lain, perubahan bunyi yang teratur pada kosakata dari bahasa-bahasa berkerabat merupakan ciri-ciri warisan dari bunyi protobahasanya.

5. Bahasa-bahasa yang berada di satu wilayah geografis seperti bahasa Sasak, bahasa Sumbawa, dan bahasa Bima, dapat diteliti dan dianalisis perbandingan bahasanya: apakah berkerabat atau bukan, dengan menggunakan dasar dan metode perbandingan bahasa.

\section{DAFTAR PUSTAKA}

Alwi, Muhammad Tahir. 2003. Kamus Bima Indonesia Inggris. Mataram: Karsa Mandiri Utama. Budasi, I Gede. 2006. Relasi Kekerabatan Genetis Kuantitatif Isolek-isolek Sumba di NTT: Sebuab Kajian Linguistik Historis Komparatif. Makalah. Denpasar: Universitas Udayana.

Chaer, Abdul. 2003. Linguistik Umum. Jakarta: Rineka Cipta.

Mahsun. 2007. Metode Penelitian Bahasa: Tahapan, Strategi, Metode, dan Teknik-tekniknya. Jakarta: Raja Grafindo.

2010. Genolinguistik: Kolaborasi Linguistik dengan Genetika dalam Pengelompokekan Bahasa dan Populasi Penuturnya. Yogyakarta: Pustaka Pelajar.

Samsuri. 1987. Analisis Bahasa. Jakarta: Erlangga.

Verhaar, J.W.M. 2006. Asas-asas Linguistik Umum. Yogyakarta: Gadjah Mada University Press. 